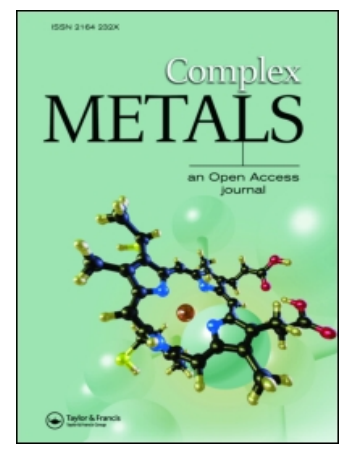

\title{
Complex Metals
}

\section{$\mathrm{Ru}(\mathrm{II})$ trithiacyclononane 5-(2-hydroxyphenyl)-3- [(4-methoxystyryl)pyrazole], a complex with facile synthesis and high cytotoxicity against PC-3 and MDA-MB-231 cells}

\author{
J. Marques, V.L.M. Silva, A.M.S. Silva, M.P.M. Marques \& S.S. Braga
}

To cite this article: J. Marques, V.L.M. Silva, A.M.S. Silva, M.P.M. Marques \& S.S. Braga (2014) $\mathrm{Ru}(\mathrm{II})$ trithiacyclononane 5-(2-hydroxyphenyl)-3-[(4-methoxystyryl)pyrazole], a complex with facile synthesis and high cytotoxicity against PC-3 and MDA-MB-231 cells, Complex Metals, 1:1, 7-12, DOI: $10.1080 / 2164232 X .2013 .873992$

To link to this article: http://dx.doi.org/10.1080/2164232X.2013.873992
(c) 2014 The Author(s). Published by Taylor \& Francis.

\section{$+\quad$ View supplementary material $๘$}

Llll Article views: 580

View Crossmark data

Published online: 14 Mar 2014.

\section{Submit your article to this journal \\ Es Submit your article to this journal t}




\title{
Complex Metals: an Open Access Journal
}

Article

\section{Ru(II) trithiacyclononane 5-(2-hydroxyphenyl)-3-[(4-methoxystyryl)pyrazole], a complex with facile synthesis and high cytotoxicity against PC-3 and MDA-MB-231 cells}

\author{
J. Marques ${ }^{\dagger}$, V.L.M. Silva ${ }^{\dagger}$, A.M.S. Silva ${ }^{\dagger}$, M.P.M. Marques ${ }^{\ddagger}$ and S.S. Braga* ${ }^{\dagger}$ \\ †QOPNA, Department of Chemistry, University of Aveiro, Aveiro, Portugal; $¥$ "Molecular Physical-Chemistry" R\&D Group, \\ Department of Life Sciences, Faculty of Science and Technology, University of Coimbra, Coimbra, Portugal
}

\begin{abstract}
The ruthenium(II) complex $\left[\mathrm{Ru}\left([9] \mathrm{aneS}_{3}\right)(\mathrm{phpz}) \mathrm{Cl}_{2}\right] \quad$ (1) $\quad\left([9] \mathrm{aneS}_{3}=\right.$ trithiacyclononane, phpz $=5-(2-$ hydroxyphenyl)-3-[(4-methoxystyryl)pyrazole]) was readily isolated by reacting $\left[\mathrm{Ru}\left([9] \mathrm{aneS}_{3}\right)\left(\mathrm{DMSO} \mathrm{Cl}_{2}\right]\right.$ with one equivalent of the ligand phpz. A combination of MS, FT-IR and solution NMR studies (1-D and 2-D) was employed to determine the structural formula of the complex 1 , in which phpz coordinates in a monodentate mode to Ru(II) by a simple replacement of the leaving group DMSO of the precursor. The cytotoxic properties of 1 in vitro were investigated by determination of the half-maximal growth inhibition on the human prostate (PC-3) and breast cancer cells (MDA-MB-231).
\end{abstract}

Keywords: Ruthenium(II); Trithiacyclononane; Hydroxyphenylpyrazoles; Cytotoxicity

Cite: Complex Met. 2014, 1, 7-12

Received 19 November 2013 Accepted 7 December 2013

\section{Introduction}

The preparation and properties of pyrazole and its analogues are a subject of consistent interest due to their wide range of applications in various areas, namely in pharmacy [1]. Known examples of pyrazole-derived active pharmaceutical ingredients include the non-steroidal antiinflammatory celecoxib $[2,3]$ and sildenafil citrate for the treatment of erectile dysfunction [4]. Several pyrazole compounds also feature cytotoxic and anti-retroviral properties [5]. Crizotinib, a pyridine-pyrazole derivative, is already in use against non-small cell lung cancer [6,7], and several new pyrazole compounds developed between 2002 and 2011 showed promising antitumor activity [8].
Within these, 3(5)-(2-hydroxyphenyl)pyrazoles are of particular relevance due to their potent inhibition of the heat shock protein 90 (Hsp90) ATPase [9], a biomolecule essential for cell growth and viability which causes resistance to chemotherapy in cancer cells [10]. Copper complexes of (2-hydroxyphenyl)pyrazoles were reported to inhibit the WM-115 melanoma cancer cell line at only half of the active concentration of cisplatin [11,12].

As part of a study exploring new 3(5)-(2-hydroxyphenyl) pyrazole structures [13], this work presents the cytotoxicity against the PC-3 and MDA-MB-231 cell lines of 5(2-hydroxyphenyl)-3-[(4-methoxystyryl)pyrazole] (phpz), both in its pure form and coordinated to ruthenium(II)trithiacyclononane.

\footnotetext{
*Corresponding author. Email: sbraga@ua.pt 


\section{Experimental section}

\subsection{Materials and methods}

The syntheses of phpz and $\left[\mathrm{Ru}\left([9] \mathrm{aneS}_{3}\right)(\mathrm{DMSO}) \mathrm{Cl}_{2}\right]$ were previously reported $[13,14]$. All other chemicals were purchased from Sigma-Aldrich (Poole, UK) and used as received. Reactions were executed using standard Schlenk techniques under nitrogen atmosphere.

Microanalyses for CHNS were performed by M. Marques on a TruSpec 630-200-200 CNHS Analyzer.

Fourrier-transform infrared (FT-IR) spectra were collected as $\mathrm{KBr}$ pellets with typically $2 \mathrm{mg}$ of sample and $200 \mathrm{mg}$ of $\mathrm{KBr}$ using a Bruker Optics Tensor 27 FTIR spectrophotometer $\left(4000-400 \mathrm{~cm}^{-1}\right.$ range, 64 scans, $2 \mathrm{~cm}^{-1}$ maximal resolution).

Mass spectra were performed using methanol as solvent and electrospray ionization (ESI-MS). Results were recorded in a Micromass ${ }^{\circledR}$ Q-ToF 2 mass spectrometer.

Nuclear magnetic resonance (NMR) studies in dimethylsulfoxide (DMSO) solution comprised 1-D $\left({ }^{1} \mathrm{H}\right.$ and $\left.{ }^{13} \mathrm{C}\right)$ and 2-D experiments, namely ${ }^{1} \mathrm{H}-{ }^{13} \mathrm{C}$ heteronuclear single quantum coherence (HSQC) and heteronuclear multiple bond coherence (HMBC) NMR spectra were recorded at ambient temperature in a Bruker Avance 300 (frequencies: $300.13 \mathrm{MHz}$ for ${ }^{1} \mathrm{H}, 75.47 \mathrm{MHz}$ for ${ }^{13} \mathrm{C}$ ) or in a Bruker DRX 500 spectrometer $\left(500.13 \mathrm{MHz}\right.$ for ${ }^{1} \mathrm{H}$ and 125.77 MHz for ${ }^{13} \mathrm{C}$ ), using the residual protic solvent signal as an internal reference (DMSO- $\mathrm{d}_{6}:{ }^{1} \mathrm{H} 2.50 \mathrm{ppm}$ and $\left.{ }^{13} \mathrm{C} 39.5 \mathrm{ppm}\right)$. Chemical shifts are quoted in parts per million (ppm).

\subsection{Preparation of $\left[R u\left([9] a n e S_{3}\right)(p h p z) C_{2}\right](1)$}

$\mathrm{Ru}\left([9] \mathrm{aneS}_{3}\right)(\mathrm{DMSO}) \mathrm{Cl}_{2} \quad(51.6 \mathrm{mg}, \quad 0.12 \mathrm{mmol}) \quad$ was added to a refluxing methanolic $(14 \mathrm{~mL})$ solution of $\mathrm{phpz}$ $(35.0 \mathrm{mg}, 0.12 \mathrm{mmol}$ ) to form a yellow suspension which dissolved after $c a$. $5 \mathrm{~min}$. The solution gradually turned from yellow to green, and a yellow precipitate started forming after $c a .30 \mathrm{~min}$. After a total of $24 \mathrm{~h}$ reflux, the hot green solution was filtered off and the remaining yellow solid was washed with methanol $(15 \mathrm{~mL})$, diethyl ether $(20 \mathrm{~mL})$ and dried (43 mg, 54\% yield).

Anal. Calcd for $\left(\mathrm{C}_{24} \mathrm{H}_{28} \mathrm{Cl}_{2} \mathrm{~N}_{2} \mathrm{O}_{2} \mathrm{RuS}_{3}\right) \cdot \mathrm{H}_{2} \mathrm{O}(662.7)$ (\%): C, 43.5; H, 4.6; N, 4.2; S, 14.5. Found: C, 43.9; H, $4.6 ; \mathrm{N}, 4.3 ; \mathrm{S}, 14.3$.

FT-IR $\left(\mathrm{Kbr}, \bar{v}_{\max }\left(\mathrm{cm}^{-1}\right)\right): 3447 \mathrm{~m}\left(v_{\mathrm{O}-\mathrm{H}}\right), 3344 \mathrm{~s}$ $\left(v_{\mathrm{N}-\mathrm{H}}\right), 1575 \mathrm{~m}\left(\nu_{\mathrm{C}=\mathrm{N}}\right), 1415 \mathrm{w}$ and $1409 \mathrm{w}\left(\delta_{\mathrm{C}-\mathrm{H}([9] \mathrm{aneS} 3)}\right)$,

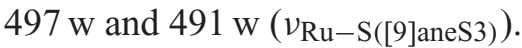

ESI $^{+}$-MS (MeOH) $m / z$ (relative intensity \%): 581 $\left(\left[\mathrm{Ru}\left([9] \mathrm{aneS}_{3}-\mathrm{CH}_{2} \mathrm{CH}_{2}\right)(\mathrm{phpz}) \mathrm{Cl}\right]^{+}, 100\right) ; 609([\mathrm{Ru}([9]$ aneS $\left.\left.\left._{3}\right)(\mathrm{phpz}) \mathrm{Cl}\right]^{+}, 72\right)$.

${ }^{1}$ H NMR $(500 \mathrm{MHz}$, DMSO-d 6$): \delta(\mathrm{ppm})=12.82(1 \mathrm{H}$, s, NH), $11.36\left(1 \mathrm{H}, \mathrm{s}, 2^{\prime}-\mathrm{OH}\right), 7.82(1 \mathrm{H}, \mathrm{d}, J=7.7 \mathrm{~Hz}$,
$\left.\mathrm{H} 6^{\prime}\right), 7.63(1 \mathrm{H}, \mathrm{d}, J=16.0 \mathrm{~Hz}, \mathrm{H} \alpha), 7.58(2 \mathrm{H}, \mathrm{d}, J=$ $\left.8.3 \mathrm{~Hz}, \mathrm{H} 2^{\prime \prime}, 6^{\prime \prime}\right), 7.53(1 \mathrm{H}, \mathrm{s}, \mathrm{H} 4), 7.38(1 \mathrm{H}, \mathrm{d}, J=$ $16.0 \mathrm{~Hz}, \mathrm{H} \beta), 7.27\left(1 \mathrm{H}, \mathrm{t}, J=7.7 \mathrm{~Hz}, \mathrm{H} 4^{\prime}\right), 7.02(1 \mathrm{H}$, $\left.\mathrm{d}, J=7.7 \mathrm{~Hz}, \mathrm{H}^{\prime}\right), 7.00\left(2 \mathrm{H}, \mathrm{d}, J=8.3 \mathrm{~Hz}, \mathrm{H}^{\prime \prime}, 5^{\prime \prime}\right)$, $6.98\left(1 \mathrm{H}, \mathrm{t}, J=7.7 \mathrm{~Hz}, \mathrm{H} 5^{\prime}\right), 3.79\left(3 \mathrm{H}, \mathrm{s}, 4^{\prime \prime}-\mathrm{OCH}_{3}\right)$, 3.10-2.58 and 2.41-2.31 (12H, m, $\left.\mathrm{CH}_{2}-[9] \mathrm{aneS}_{3}\right)$.

${ }^{13} \mathrm{C}$ NMR $\left(75 \mathrm{MHz}, \quad\right.$ DMSO- $\left.\mathrm{d}_{6}\right): \quad \delta(\mathrm{ppm})=159.7$ (C4"), $154.4\left(\mathrm{C}^{\prime}, 3\right), 143.7(\mathrm{C} 5), 133.5(\mathrm{C} \beta), 130.7\left(\mathrm{C}^{\prime}\right)$, $129.2\left(\mathrm{Cl}^{\prime \prime}\right), 128.3\left(\mathrm{C} 2^{\prime \prime}, 6^{\prime \prime}\right), 127.6\left(\mathrm{C}^{\prime}\right), 120.1\left(\mathrm{C} 5^{\prime}\right)$, $116.6\left(\mathrm{C} 3^{\prime}, \alpha\right), 114.5\left(\mathrm{C} 3^{\prime \prime}, 5^{\prime \prime}\right), 113.8\left(\mathrm{Cl}^{\prime}\right), 100.9(\mathrm{C} 4)$, $55.3\left(4^{\prime \prime}-\mathrm{OCH}_{3}\right), 37.4,35.1,34.6,34.3,33.9,33.2,32.9$, $32.7,32.6,32.4,30.9,30.7\left(\mathrm{CH}_{2}-[9] \mathrm{aneS}_{3}\right)$.

\subsection{Cytotoxicity studies}

The complex 1, phpz and cisplatin (used as positive control) were tested on the human PC-3 prostate (androgen-independent) and the MDA-MB-231 (estrogen-

independent) breast cancer cell lines, using the mitochondrial dehydrogenase activity assay (MTT) for cell viability evaluation.

2.3.1. Preparation of solutions. Stock solutions of compound $1(4.85 \mathrm{mM})$ and the free ligand phpz $(10 \mathrm{mM})$ were prepared in DMSO. Cisplatin was prepared in a concentration of $1.25 \mathrm{mM}$ in phosphate buffered saline (PBS) $\left(140.0 \times 10^{-3} \mathrm{M} \mathrm{NaCl}, 2.7 \times 10^{-3} \mathrm{M} \mathrm{KCl}, 1.5 \times 10^{-3} \mathrm{M}\right.$ $\mathrm{KH}_{2} \mathrm{PO}_{4}, 8.1 \times 10^{-3} \mathrm{M} \mathrm{Na}_{2} \mathrm{HPO}_{4}$ in Milli-Q water, $\mathrm{pH}$ 7.4) and sterilized by filtration. Stock solutions were diluted to obtain the test solutions at the concentrations required for the biological assays. In all the experiments, for both control and treated samples, the highest concentrations of DMSO and PBS in each well were $0.5 \%(v / v)$ and $2 \%(v / v)$, respectively. MTT was prepared in PBS $\left(5 \mathrm{mg} \mathrm{mL}^{-1}\right)$ and sterilized by filtration.

2.3.2. Cell culture. The MDA-MB- 231 cell line (human Caucasian estrogen-independent breast adenocarcinoma) was purchased from the European Collection of Cell Cultures (ECACC, Salisbury, UK), while the PC-3 line (human Caucasian androgen-independent prostate cancer) was kindly provided by the Faculty of Medicine's Biochemistry Service, University of Coimbra (Portugal).

The two cell lines were grown in monolayers in $75 \mathrm{~cm}^{2}$ tissue culture flasks at $37^{\circ} \mathrm{C}$ in a humidified atmosphere with $5 \% \mathrm{CO}_{2}$, sub-cultured every 23 days and harvested upon addition of trypsin/EDTA ( $0.05 \%$ trypsin/EDTA solution). The culture medium was RPMI 1640, supplemented with sodium bicarbonate $\left(1.5 \mathrm{~g} \mathrm{~L}^{-1}\right), 10 \%$ heat-inactivated fetal bovine serum (FBS) and penicillin-streptomycin (100 units $\mathrm{mL}^{-1}$ penicillin and $100 \mu \mathrm{g} \mathrm{mL}^{-1}$ streptomycin) for PC-3 cells 
and with sodium bicarbonate $\left(1.5 \mathrm{~g} \mathrm{~L}^{-1}\right), 10 \%$ heatinactivated FBS, non-essential amino acids (1 mM), penicillin-streptomycin $\left(100\right.$ units $\mathrm{mL}^{-1}$ penicillin and $100 \mu \mathrm{g} \mathrm{mL}^{-1}$ streptomycin) and sodium pyruvate $(1 \mathrm{mM})$ for MDA-MB-231 cells.

2.3.3. Viability assay. Cell viability following exposure of the PC-3 and MDA-MB-231 cells to test solutions with different concentrations of $\mathbf{1}, \mathrm{phpz}$ and cisplatin was assessed at $72 \mathrm{~h}$ of incubation. Each concentration was tested by three independent experiments with triplicates. PC-3 and MDA-MB-231 cells were plated at a density of $1.5 \times 10^{4} \mathrm{cells} \mathrm{cm}^{-2}$ in 48 -well microplates. The test solutions were added $24 \mathrm{~h}$ after seeding and incubated at $37^{\circ} \mathrm{C}$. After $72 \mathrm{~h}, 55 \mu \mathrm{L}$ of MTT was added to each well, and the plates were incubated for $2 \mathrm{~h}$. Then, MTT was removed and the cells washed with $200 \mu \mathrm{L}$ of DMSO under stirring to remove the purple formazan crystals. The optical density was measured in a microplate reader, at $570 \mathrm{~nm}$.

2.3.4. Statistical analysis. The statistical analysis of the results was performed by analysis of variance, using the Dunnett's post hoc test for statistical comparison between the experimental data, $p$-values $<0.05$ being deemed significant. The $\mathrm{IC}_{50}$ values were determined using nonlinear regression analysis, fitting the results in sigmoidal dose-response curves (variable slope).

\section{Results and discussion}

The complex $\left[\mathrm{Ru}\left([9] \mathrm{aneS}_{3}\right)(\mathrm{phpz}) \mathrm{Cl}_{2}\right]$ (1) precipitated as a yellow microcrystalline solid (powder diffractogram available as supplementary information) from the reaction of $\left[\mathrm{Ru}\left([9] \mathrm{aneS}_{3}\right)\left(\mathrm{DMSO} \mathrm{Cl}_{2}\right]\right.$ with one molar equivalent of phpz. It is partially soluble in polar solvents such as dimethylsulfoxide, methanol or water.

As will be described below, solution-phase NMR studies of the complex 1 revealed that the coordination of the ligand phpz occurred in a monodentate fashion at the $\mathrm{N} 2$ of the pyrazole moiety (Figure 1). The FT-IR spectrum of $\mathbf{1}$, though not showing the $\mathrm{Ru}-\mathrm{N}$ vibration which lies below $400 \mathrm{~cm}^{-1}$, is in accordance with this structure since a redshift is observed for the pyrazole's $\mathrm{N}-\mathrm{H}$ and $\mathrm{C}=\mathrm{N}$ bands, associated with metal coordination [15]. The $\mathrm{N}-\mathrm{H}$ stretch suffers a redshift and the $\mathrm{O}-\mathrm{H}$ stretch, absent from the spectrum of phpz, appears as a broad band at $3447 \mathrm{~cm}^{-1}$.

The positive ESI-MS spectrum of 1 (in methanol) shows the most intense peak at $m / z=581$, corresponding to $\left[\mathrm{Ru}\left([9] \mathrm{aneS}_{3}-\mathrm{CH}_{2} \mathrm{CH}_{2}\right)(\mathrm{phpz}) \mathrm{Cl}\right]^{+}$, a fragment generated by the loss of one ethylene unit of trithiacyclononane

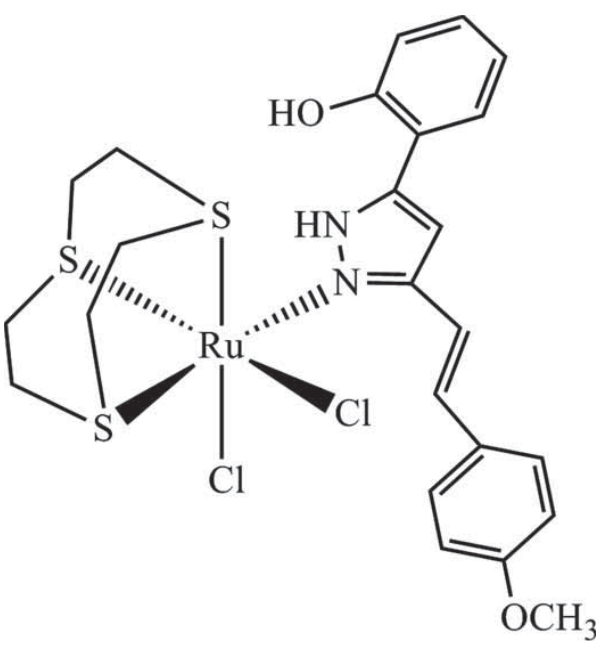

Figure 1. Structure of complex 1.

along with one chloride, while the peak of the molecular cation, $\left[\mathrm{Ru}\left([9] \mathrm{aneS}_{3}\right)(\mathrm{phpz}) \mathrm{Cl}\right]^{+}(m / z=609)$, is second in intensity.

Solution-phase NMR studies determined the structure and geometry of the coordinated phpz in complex $\mathbf{1}$. Free phpz, like most pyrazoles, has two tautomers (Figure 2), along with a trans-vinylic system $(\mathrm{C} \alpha=\mathrm{C} \beta)$. Its ${ }^{1} \mathrm{H}$ NMR spectrum, represented in Figure 3 (bottom), presents four deshielded broad singlets attributed to the $\mathrm{NH}$ and $\mathrm{C}^{\prime}$ $\mathrm{OH}$ resonances of the two prototropic isomer forms. The hydroxyl proton usually appears at a higher frequency than the $\mathrm{NH}$ because it is involved in an intramolecular hydrogen bond with the $\mathrm{N} 2(\mathrm{OH} \cdots \mathrm{N}$ tautomer, phpz-I). In a DMSO- $\mathrm{d}_{6}$ solution, this $\mathrm{OH} \cdots \mathrm{N} 2$ bridge is partially replaced by another with DMSO and the resonances of the NH. . O tautomer (phpz-II) can be observed, although with less intensity. Indeed, the two most intense signals $\left(\mathrm{C}^{\prime}-\mathrm{OH}\right.$ at 13.32 and $\mathrm{NH}$ at $\left.10.91 \mathrm{ppm}\right)$ of the spectrum of the phpz ligand are ascribed to phpz-I and the two less intense $\left(2^{\prime}-\mathrm{O} H-12.77\right.$ and $\left.\mathrm{N} H-10.25 \mathrm{ppm}\right)$ to phpz-II.

In the ${ }^{1} \mathrm{H}$ NMR spectrum of the complex 1 (Figure 3, top), the $\mathrm{H} \beta$ signal of coordinated phpz is slightly shifted downfield $(0.17 \mathrm{ppm})$ and the $\mathrm{H} \alpha$ affords a doublet $\left({ }^{3} J_{\alpha, \beta}\right.$ $16.0 \mathrm{~Hz}$ ), indicating a trans configuration for $\mathrm{C} \alpha=\mathrm{C} \beta$ in the $\mathrm{Ru}$-coordinated phpz. The $\mathrm{NH}$ proton appears deshielded to $12.82 \mathrm{ppm}$ (shift of $2.57 \mathrm{ppm}$ ), which is associated with N2-coordination of phpz to the ruthenium cation (details in the next paragraph) and with the presence of an $\mathrm{NH} \cdots \mathrm{O}$ bridge with the hydroxyl (i.e. ruthenium-coordinated phpz-II). The resonances of the methoxybenzene moiety are unshifted, and the [9] $\mathrm{aneS}_{3}$ macrocycle appears as a multiplet at $3.10-2.58 \mathrm{ppm}$. A summary of the ${ }^{1} \mathrm{H}$ NMR spectral data for the complex 1 and the pure ligand is presented in Table 1.

The 2-D NMR evidences monodentate coordination of the phpz-II tautomer to $\mathrm{Ru}(\mathrm{II})[9] \mathrm{aneS}_{3}$ via the $\mathrm{N} 2$ 
<smiles></smiles>

phpz-I<smiles>COc1ccc(/C=C/c2cc3n(n2)[IH]Oc2ccccc2-3)cc1</smiles>

phpz-II

Figure 2. Two tautomeric forms I and II of phpz with the corresponding carbon labeling.
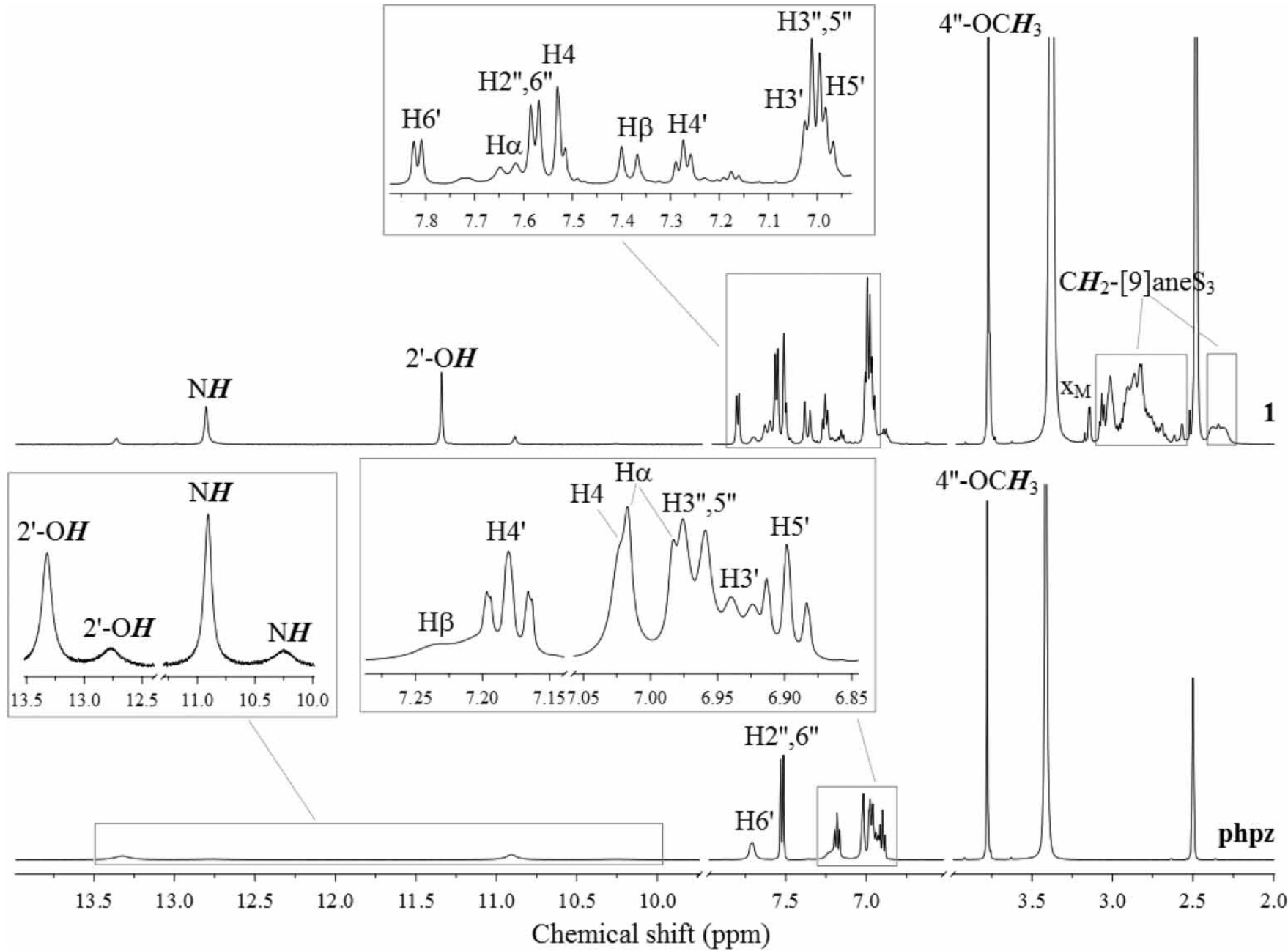

Figure 3. ${ }^{1} \mathrm{H}$ NMR spectrum in DMSO- $\mathrm{d}_{6}$ solution of the free phpz ligand (bottom) and of the complex 1 (top). $\mathrm{x}_{M}-$ free $\mathrm{MeOH}$.

position. The resonances of the carbon atoms can be observed in the ${ }^{13} \mathrm{C}$ NMR 1-D spectrum of 1 (Figure 4, top) and their chemical shift values are listed in Table 2. Within the methine carbons (identified by the ${ }^{1} J$ HSQC correlations) the highest downfield shift was observed in the $\mathrm{C} \alpha$ (ca. $4 \mathrm{ppm})$, followed closely by the quaternary pyrazolylic carbons $\mathrm{C} 3$ and $\mathrm{C} 5$ (identified by ${ }^{2} J$ and ${ }^{3} J$ HMBC correlations) and the $\mathrm{C} \beta$ ( $c a .2-3 \mathrm{ppm})$. In turn, the phenolic $\mathrm{C}^{\prime}$ and $\mathrm{C}^{\prime}$ appear shifted upfield (ca. 1$3 \mathrm{ppm}$ ); these shifts, in association with the shift of the
$2^{\prime}-\mathrm{OH}$ proton (also identified from HMBC correlations) allow us to infer that the $\mathrm{O}-\mathrm{H} \cdots d s$ bridge ( $d s$ : deuterated solvent) in $\mathbf{1}$ is weaker than in free phpz-II. The carbons of the methoxybenzene were not affected by the coordination, similar to their corresponding proton signals. Trithiacyclononane carbons afford 12 resonances (with six sharp and six broad signals) between 37.4 and $30.7 \mathrm{ppm}$.

The cytotoxicity of phpz and $\mathbf{1}$ in comparison with cisplatin was evaluated against the PC-3 prostate and MDA-MB-231 breast cancer cell lines (Table 3). Phpz 

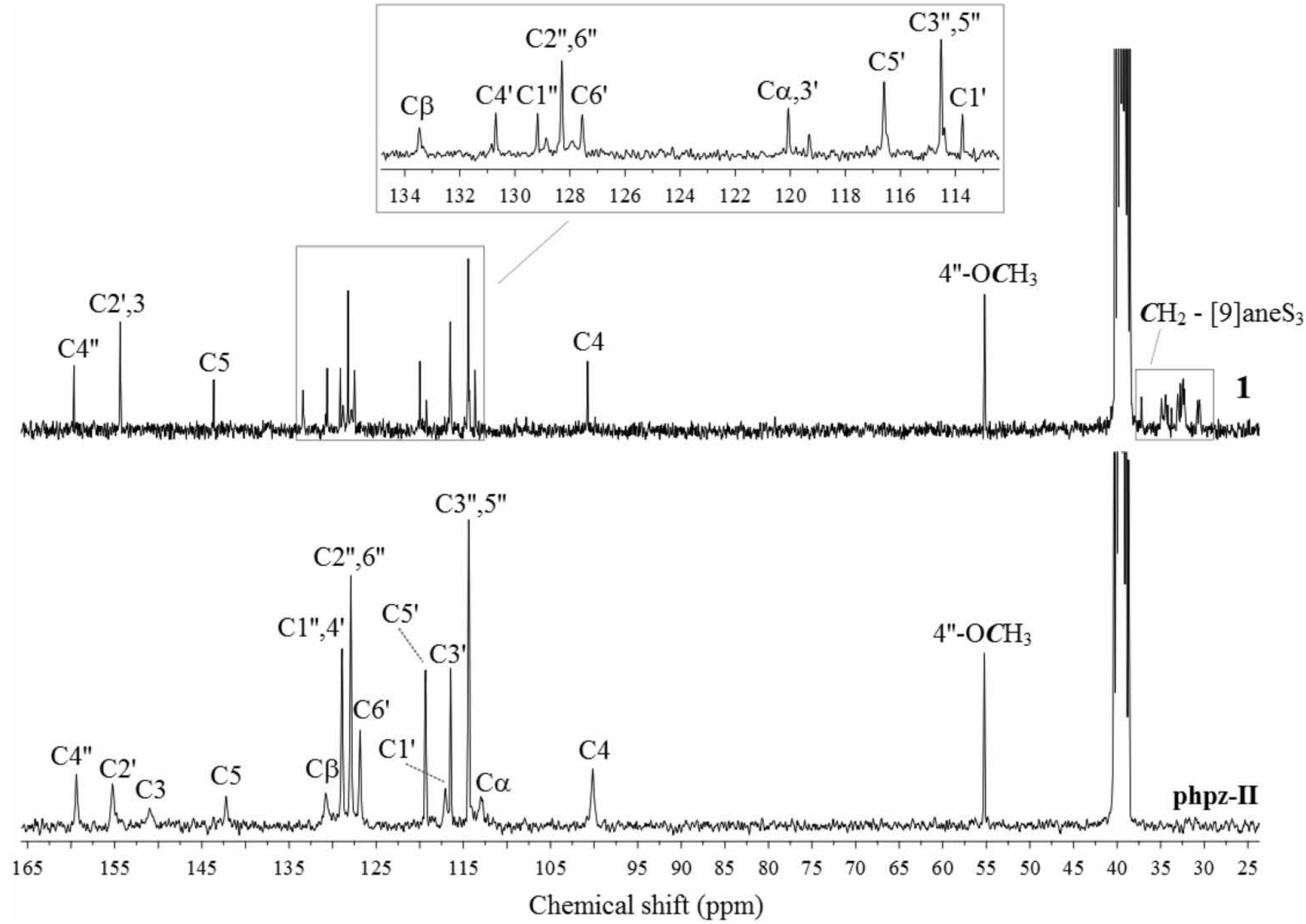

Figure 4. ${ }^{13} \mathrm{C}$ NMR spectrum in DMSO- $\mathrm{d}_{6}$ of the phpz ligand in the the tautomeric form II (bottom) and of the complex 1 (top).

Table 1. ${ }^{1} \mathrm{H}$ NMR chemical shifts and proton coupling constants of the ligand phpz and the complex 1 in DMSO- $\mathrm{d}_{6}$.

\begin{tabular}{|c|c|c|c|c|}
\hline \multirow[b]{2}{*}{ Attribution } & \multicolumn{2}{|l|}{ phpz } & \multicolumn{2}{|l|}{1} \\
\hline & $\begin{array}{c}{ }^{1} \mathbf{H} \\
(\mathbf{p p m})\end{array}$ & $\begin{array}{c}J \\
(\mathbf{H z})\end{array}$ & $\begin{array}{c}{ }^{1} \mathbf{H} \\
(\mathbf{p p m})\end{array}$ & $\begin{array}{c}J \\
(\mathbf{H z})\end{array}$ \\
\hline$"-\mathrm{OCH}_{3}$ & $3.78(\mathrm{~s})$ & - & $3.79(\mathrm{~s})$ & - \\
\hline $\mathrm{H} 2^{\prime \prime}, \mathrm{H} 6^{\prime \prime}$ & 7.52 (d) & 8.6 & 7.58 (d) & 8.3 \\
\hline $\mathrm{H} 3^{\prime \prime}, \mathrm{H} 5^{\prime \prime}$ & 6.97 (d) & 8.6 & 7.00 (d) & 8.3 \\
\hline $2^{\prime}-\mathrm{O} \boldsymbol{H}(\mathrm{phpz}-\mathrm{I})$ & $13.32(\mathrm{br} \mathrm{s})$ & - & - & - \\
\hline 2'-O H (phpz-II $)$ & 12.77 (br s) & - & $11.36(\mathrm{~s})$ & - \\
\hline $\mathrm{H} 3^{\prime}$ & $6.93(d)$ & 7.7 & 7.02 (d) & 7. \\
\hline $\mathrm{H} 4^{\prime}$ & $7.16-7.20(\mathrm{~m})$ & - & $7.27(\mathrm{t})$ & 7. \\
\hline H5 & $6.90(\mathrm{t})$ & 7.7 & $6.98(\mathrm{t})$ & 7. \\
\hline $\mathrm{H} 6^{\prime}$ & 7.71 (br s) & - & 7.82 (d) & 7. \\
\hline $\mathrm{H} 4$ & $7.02(\mathrm{~s})$ & - & $7.53(\mathrm{~s})$ & - \\
\hline $\mathrm{H} \alpha$ & $7.00(\mathrm{~d})$ & 17.2 & 7.63 (d) & 16.0 \\
\hline $\mathrm{H} \beta$ & 7.23 (brs) & - & $7.38(\mathrm{~d})$ & 16.0 \\
\hline $\mathrm{N} \boldsymbol{H}(\mathrm{phpz}$ & 10.91 (br s) & - & - & - \\
\hline $\mathrm{NH}$ (phpz-II) & $10.25(\mathrm{br} \mathrm{s})$ & - & $12.82(\mathrm{~s})$ & - \\
\hline $\mathrm{CH}_{2}-[9] \mathrm{aneS}_{3}$ & - & - & $3.10-2.58(\mathrm{~m})$ & - \\
\hline
\end{tabular}

Note: The DMSO-d 6 signal $(2.50 \mathrm{ppm})$ was used as the internal reference.
Table 2. ${ }^{13} \mathrm{C}$ NMR chemical shifts of the tautomer phpz-II and the complex $\mathbf{1}$ in DMSO-d $\mathrm{d}_{6}$.

\begin{tabular}{|c|c|c|}
\hline Attribution & phpz-II & 1 \\
\hline $\begin{array}{l}4^{\prime \prime}-\mathrm{O} \mathrm{CH}_{3} \\
\mathrm{C} 1^{\prime \prime} \\
\mathrm{C} 2^{\prime \prime} \\
\mathrm{C} 3^{\prime \prime} \\
\mathrm{C} 4^{\prime \prime} \\
\mathrm{C} 5^{\prime \prime} \\
\mathrm{C} 6^{\prime \prime} \\
\mathrm{C} 1 \prime \\
\mathrm{C} 2 \prime \\
\mathrm{C} 3 \prime \\
\mathrm{C} 4 \prime \\
\mathrm{C} 5 \prime \\
\mathrm{C} 6{ }^{\prime} \\
\mathrm{C} 3 \\
\mathrm{C} 4 \\
\mathrm{C} 5 \\
\mathrm{C} \alpha \\
\mathrm{C} \beta \\
\mathrm{CH} \mathrm{H}_{2}-[9] \mathrm{aneS}_{3}\end{array}$ & $\begin{array}{r}55.3 \\
128.9 \\
127.9 \\
114.4 \\
159.4 \\
114.4 \\
127.9 \\
117.1 \\
155.2 \\
116.5 \\
128.9 \\
119.3 \\
126.9 \\
151.0 \\
100.1 \\
142.2 \\
113.0 \\
130.8 \\
-\end{array}$ & $\begin{array}{r}55.3 \\
129.2 \\
128.3 \\
114.5 \\
159.7 \\
114.5 \\
128.3 \\
113.8 \\
154.4 \\
116.6 \\
130.7 \\
120.1 \\
127.6 \\
154.4 \\
100.9 \\
143.7 \\
116.6 \\
133.5 \\
37.4,35.1,34.6,34.3, \\
33.9,33.2,32.9,32.7, \\
32.6,32.4,30.9,30.7\end{array}$ \\
\hline
\end{tabular}

Note: The DMSO- $\mathrm{d}_{6}$ signal $(39.5 \mathrm{ppm})$ was used as the internal reference. 
Table 3. Inhibition ( $\mathrm{IC}_{50}$ values) at $72 \mathrm{~h}$ of incubation of PC-3 and MDA-MB-231 cells by phpz and $\mathbf{1}$.

\begin{tabular}{lrc}
\hline & \multicolumn{2}{c}{ IC $_{50}(\mu \mathbf{M})$} \\
\cline { 2 - 3 } & PC-3 & MDA-MB-231 \\
\hline phpz & 9.9 & 10.2 \\
1 & 32.3 & 19.2 \\
cisplatin $^{\mathrm{a}}$ & 6.6 & 9.5 \\
\hline
\end{tabular}

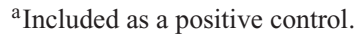

displayed the expected high biological activity, with $\mathrm{IC}_{50}$ values comparable to those of cisplatin. Several such pyrazoles have antineoplasic action, coupled with low toxic profiles [16]. Moreover, structure-activity relationship studies on the growth inhibition of MCF-7 cells by 2-hydroxyphenylated 4,5-dihydro- $2 \mathrm{H}$-pyrazoles evidenced higher activity $\left(\mathrm{IC}_{50} \leq 4 \mu \mathrm{M}\right)$ associated with a para electron-donating $\mathrm{OCH}_{3}$ group [17].

Complex 1 has $\mathrm{IC}_{50}$ values of $19.2 \mu \mathrm{M}$ and $32.3 \mu \mathrm{M}$, respectively, against the MDA-MB-231 and PC-3 cells. While lower to phpz's, the activity of 1 against MDA-MB231 is nonetheless $4 \times$ superior to $\left[\mathrm{Ru}\left([9] \mathrm{aneS}_{3}\right)(\mathrm{en}) \mathrm{Cl}\right]$, the most active $\mathrm{Ru}(\mathrm{II})$-trithiacyclononane reported to date [18].

\section{Conclusion}

The new complex herein presented, $\left[\mathrm{Ru}\left([9] \mathrm{aneS}_{3}\right)(\mathrm{phpz})\right.$ $\mathrm{Cl}_{2}$ ] (1), combines a facile one-step synthesis with a notable cytotoxic action towards the MDA-MB-231 and PC-3 human cancer cell lines. Given its potential value, both phpz and the complex 1 warrant further studies on healthy human cells, regarding toxicological safety. Should these studies demonstrate that coordination to ruthenium plays a key role in the selectivity of action of phpz towards cancer cells, the coordination of phpz to other ruthenium scaffolds will be contemplated as a follow-up study.

\section{Supplementary material}

Powder X-ray diffraction data and tables with the full listing and description of the ${ }^{1} \mathrm{H}$ and ${ }^{13} \mathrm{C}$ chemical shifts of the organic ligand phpz and the complex $\mathbf{1}$ are presented as electronic supplementary information.

\section{Funding}

We acknowledge Fundação para a Ciência e a Tecnologia (FCT), the European Union, QREN, FEDER, COMPETE, for funding QOPNA (Organic Chemistry Research Unit) (project PEst-C/QUI/UI0062/2013; FCOMP-010124-FEDER-037296). The FCT and the European Social Fund, through the Programa Operacional Potencial Humano (POPH), are acknowledged for J.M.'s Ph.D. grant (SFRH/BD/44791/2008).

\section{Supplemental data}

Supplemental data for this article can be accessed http://dx.doi.org/10.1080/2164232X.2013.873992.

\section{References}

[1] J. Elguero. In Comprehensive Heterocyclic Chemistry II, A.R. Katritzky, C.W. Rees, E.F.V. Scriven (Eds), pp. 1-75, Pergamon, Oxford (1996).

[2] T.D. Penning, J.J. Talley, S.R. Bertenshaw, J.S. Carter, P.W. Collins, S. Docter, M.J. Graneto, L.F. Lee, J.W. Malecha, J.M. Miyashiro, R.S. Rogers, D.J. Rogier, S.S. Yu, G.D. Anderson, E.G. Burton, J.N. Cogburn, S.A. Gregory, C.M. Koboldt, W.E. Perkins, K. Seibert, A.W. Veenhuizen, Y.Y. Zhang, P.C. Isakson. J. Med. Chem., 40, 1347 (1997).

[3] J.-M. Dogné, C.T. Supuran, D. Pratico. J. Med. Chem., 48, 2251 (2005).

[4] H. Padma-Nathan. Int. J. Impot. Res., 18, 423 (2006).

[5] T. Mizuhara, T. Kato, A. Hirai, H. Kurihara, Y. Shimada, M. Taniguchi, H. Maeta, H. Togami, K. Shimura, M. Matsuoka, S. Okazaki, T. Takeuchi, H. Ohno, S. Oishi, N. Fujii. Bioorg. Med. Chem. Lett., 23, 4557 (2013).

[6] G. Scagliotti, R.A. Stahel, R. Rosell, N. Thatcher, J.-C. Soria. Eur J. Cancer, 48, 961 (2012).

[7] W.T. Elliott, C. James. Intern. Med. Alert, 33, 142 (2011).

[8] D. Pal, S. Saha, S. Singh. Int. J. Pharm. Pharm. Sci., 4, 98 (2012).

[9] P.A. Brough, X. Barril, M. Beswick, B.W. Dymock, M.J. Drysdale, L. Wright, K. Grant, A. Massey, A. Surgenor, P. Workman. Bioorg. Med. Chem. Lett., 15, 5197 (2005).

[10] G. Jego, A. Hazoumé, R. Seigneuric, C. Garrido. Cancer Lett., 332, 275 (2013).

[11] E. Budzisz, M. Miernicka, I.-P. Lorenz, P. Mayer, U. Krajewska, M. Rozalski. Polyhedron, 28, 637 (2009).

[12] E. Budzisz, M. Miernicka, I.-P. Lorenz, P. Mayer, E. Balcerczak, U. Krajewska, M. Rozalski. Eur. J. Med. Chem., 45, 2613 (2010).

[13] V.L.M. Silva, A.M.S. Silva, D.C.G.A. Pinto, J.A.S. Cavaleiro, J. Elguero. Eur. J. Org. Chem., 2004, 4348 (2004).

[14] C. Landgrafe, W.S. Sheldrick. J. Chem. Soc., Dalton Trans., 1885 (1994).

[15] S.M.E. Khalil. J. Coord. Chem., 56, 1013 (2003).

[16] R.M. Mohareb, A.A. Fahmy. Eur. Chem. Bull., 2, 545 (2013).

[17] J.-J. Liu, H. Zhang, J. Sun, Z.-C. Wang, Y.-S. Yang, D.-D. Li, F. Zhang, H.-B. Gong, H.-L. Zhu. Bioorg. Med. Chem., 20, 6089 (2012).

[18] I. Bratsos, E. Mitri, F. Ravalico, E. Zangrando, T. Gianferrara, A. Bergamo, E. Alessio. Dalton Trans., 41, 7358 (2012). 